\title{
Effects of Storage on Venous and Capillary Blood Samples: The Influence of Deferoxamine and Butylated Hydroxytoluene on the Fatty Acid Alterations in Red Blood Cell Phospholipids
}

\author{
Suzie J. Otto, Magritha M. H. P. Foreman-v. Drongelen, Adriana C. v. Houwelingen and Gerard Hornstra \\ Department of Human Biology, Maastricht University, Maastricht, The Netherlands
}

\begin{abstract}
Summary: Fatty acid concentrations in plasma and red blood cell phospholipids isolated from paired venous and capillary blood samples were compared and the effect of storage at $-20^{\circ} \mathrm{C}$ was evaluated as well. Plasma fatty acid profiles from venous and capillary blood were found to be comparable and not affected by up to four weeks of storage, while fatty acid profiles of venous and capillary red blood cells were no longer comparable after four weeks. Substantial losses of long-chain polyunsaturated fatty acids were observed in capillary red blood cells.
\end{abstract}

To investigate whether the observed long-chain polyunsaturated fatty acids loss could be prevented, capillary red blood samples were stored for up to one year at $-50^{\circ} \mathrm{C}$ in the presence of the iron-binding agent deferoxamine or the free radical scavenger butylated hydroxytoluene. Both compounds protected the long-chain polyunsaturated fatty acids. Similarly, storage of red blood cell lipid extracts at $-50^{\circ} \mathrm{C}$ for up to one year was not associated with reduced levels of long-chain polyunsaturated fatty acids.

In conclusion, the lipid loss from capillary red blood cells can be reduced for at least one year during storage at $-50{ }^{\circ} \mathrm{C}$ with prior addition of either a metal chelating compound or a free radical scavenger, or by preparing lipid extracts of the samples within one week of blood collection.

\section{Introduction}

To study the human essential fatty acid status, blood samples are usually collected through venipuncture. Studies in preterm infants, however, often rely on 'diagnostic' blood samples, which can be of either venous or capillary origin. As a result, longitudinally collected sets of blood samples are likely to contain both venous and capillary bloods. The fatty acid profiles of venous and capillary plasma and red blood cell phospholipids should, therefore, be comparable.

A few studies in which the fatty acid compositions of venous and capillary plasma were compared have yielded ambiguous results $(1,2)$. Therefore, the initial aim of the present study was to compare phospholipidassociated fatty acid profiles of plasma and red blood cells, collected through either venous or capillary puncture. In addition, the effects of storage at $-20{ }^{\circ} \mathrm{C}$ for a period up to four weeks on both venous and capillary plasma and red blood cell phospholipids was evaluated. The results showed alterations in the polyunsaturated fatty acids composition of capillary red blood cell phospholipids, probably due to oxidation. To protect these fatty acids, an experiment was subsequently carried out, in which capillary red blood cell samples were stored at $-50{ }^{\circ} \mathrm{C}$ for up to one year in the presence of an antioxidant (butylated hydroxytoluene) or an iron chelator (deferoxamine). In addition, red blood cell lipid extracts were prepared immediately upon sampling and also stored at $-50^{\circ} \mathrm{C}$ for a period up to 44 weeks. The fatty acid content of the phospholipids was analyzed at several intervals during this period.

\section{Methods and Subjects}

Experimental design

Comparison of venous and capillary plasma and red blood cell phospholipids

Blood samples were collected from eight healthy adults ( 3 males, 5 females, aged 26-30 years) from an antecubital vein in EDTA vacutainer tubes $(5 \mathrm{ml}$ ) and from the fingertip (approximately $2 \mathrm{ml}$ ) in microtainer tubes containing EDTA.

The plasma was separated from the red blood cells by centrifugation $\left(10 \mathrm{~min}, 3000 \mathrm{~min}^{-1}, 4^{\circ} \mathrm{C}\right)$. Red blood cells were washed twice $\left(15 \mathrm{~min}, 1500 \mathrm{~min}^{-1}, 4^{\circ} \mathrm{C}\right.$ ) with EDTA-containing saline $\left(\mathrm{Na}_{2}\right.$ EDTA $\left.\cdot 2 \mathrm{H}_{2} \mathrm{O} 28.64 \mathrm{~g}, \mathrm{NaCl} 7 \mathrm{~g}, \mathrm{H}_{2} \mathrm{O} 1000 \mathrm{ml}\right)$.

For the additional evaluation of a possible effect of storage on the fatty acids, aliquots of the plasma and red blood cell samples of each participant were divided into polypropylene storage cups and stored at $-20^{\circ} \mathrm{C}$ for one and four weeks before lipid extraction. The cups were closed under a stream of nitrogen to prevent oxidation. The lipid extraction of one aliquot of each plasma and red blood cell sample was performed on the same day of blood collection. To ensure uniformity of analytical conditions, the venous and capillary blood samples of each subject were analyzed simultaneously.

\section{Preservation of the lipids}

Approximately $3.5 \mathrm{ml}$ of capillary blood were collected from eleven healthy subjects ( 4 males, 7 females, aged $23-55$ years) by 
finger-prick into EDTA-containing tubes. The plasma was separated from the red blood cells by centrifugation. After washing the red blood cells with EDTA-containing saline, the suspensions were collected in screw-capped tubes. To facilitate oxidation of the lipids, the red blood cells were destructed by 1 cycle of freezing ( 30 min in liquid nitrogen) and thawing.

Subsequently, aliquots of $50 \mu \mathrm{l}$ of each red blood cell sample were taken for immediate lipid extraction and for preparing six duplicate samples to which $2 \mu \mathrm{l}$ of a butylated hydroxytoluene $(500 \mathrm{mg} / \mathrm{l})$ or a deferoxamine $(18.75 \mathrm{~g} / \mathrm{l})$ solution was added. The polypropylene storage cups were closed under a stream of nitrogen and stored at $-50^{\circ} \mathrm{C}$.

To study the effect of these storage conditions on the fatty acid content of the red blood cell samples, the seven sample sets of each subject were analyzed on the day of collection, and 2, 4, 8 , 16,32 and 52 weeks thereafter.

From the remaining capillary red blood cell sample $(600 \mu \mathrm{l})$ of each subject, lipid extracts were prepared on the day of blood collection. Each lipid extract was equally divided into 11 screwcapped vials, which were closed under a stream of nitrogen and stored at $-50^{\circ} \mathrm{C}$. The fatty acid content was analyzed every four weeks, up to 44 weeks. Informed consent was obtained from all participants.

\section{Fatty acid analysis}

After addition of an internal standard, 1,2-dinonadecanoyl phosphatidylcholine, total lipid extracts of plasma or red blood cell suspensions were prepared according to the method of Bligh \& Dyer (3). Heptadecaenoic acid $(17: 1)$ was added to the samples to check for any carry-over of free fatty acids during the isolation of phospholipids. The phospholipid fractions were isolated by solid phase extraction from the total lipid extracts on aminopropyl-silica columns (4). The resulting phospholipids were saponified and the fatty acids converted to the corresponding methyl esters by reaction with $140 \mathrm{~g} / 1$ boron trifluoride in methanol at $100^{\circ} \mathrm{C}$ for one hour (5). To all organic solvents, butylated hydroxytoluene $(50 \mathrm{mg} / \mathrm{l})$ was added as an antioxidant. The fatty acid composition of the phospholipids was determined by capillary gas liquid chromatography as described before (6), only modified by the use of a CP-Sil 88 column (Chrompack ${ }^{\circledR}$, Middelburg, The Netherlands). Fatty acid amounts present in the phospholipid fraction were quantified based on the amount of 19:0 internal standard fatty acid methyl ester recovered. The results are expressed as $\mathrm{mg} / \mathrm{l}$ plasma or red blood cell suspension and as percent $(\mathrm{mg} / 100 \mathrm{mg}$ ) of total fatty acids.

\section{Data analysis \\ Comparison of venous and capillary plasma and red blood cell phospholipids}

Fatty acid concentrations are presented as medians and inter-quartile ranges and compared for each of the three intervals between blood sampling and lipid extraction (zero days, one week and four weeks). In addition, fatty acid concentrations in samples of which lipids were extracted one or four weeks after blood collection were compared with fatty acid concentrations in samples extracted on the day of blood sampling. The results were evaluated by the twotailed Wilcoxon signed rank test.

Butylated hydroxytoluene and deferoxamine in red blood cell suspensions

Possible changes over time in the fatty acid composition of red blood cell samples stored in the presence of butylated hydroxytoluene or deferoxamine were studied by calculating the slope (regression coefficient) of a given fatty acid for each participant. To enable the calculation of a linear regression coefficient, the logarithms of the storage times $(2,4,8,16,32$ and 52 weeks) were used in the analysis. For each fatty acid, the average slope was compared to zero by the two-tailed Wilcoxon signed rank test.

\section{Red blood cell lipid extracts}

The data of the stored red blood cell lipid extracts were analyzed by calculating the slopes by linear regression analysis and, thereafter, evaluated by the two-tailed Wilcoxon signed rank test.

Because of multiple comparisons, P-values $<0.01$ were considered significantly different.

\section{Results}

Comparison of venous and capillary plasma and red blood cell phospholipids

There was no difference between venous and capillary plasma phospholipids with respect to the absolute amounts $(\mathrm{mg} / \mathrm{l})$ of the fatty acids after one or four weeks of storage at $-20^{\circ} \mathrm{C}$ before lipid extraction (fig. 1). This also holds for the absolute amounts of the fatty acid of venous and capillary red blood cell phospholipids extracted on the day of blood collection and one week thereafter (fig. 1). In venous red blood cells, four weeks of storage before lipid extraction did not result in significantly different fatty acid levels, when compared with the samples extracted on the day of collection. In capillary red blood cell phospholipids, however, substantial differences from the initial values were observed in the
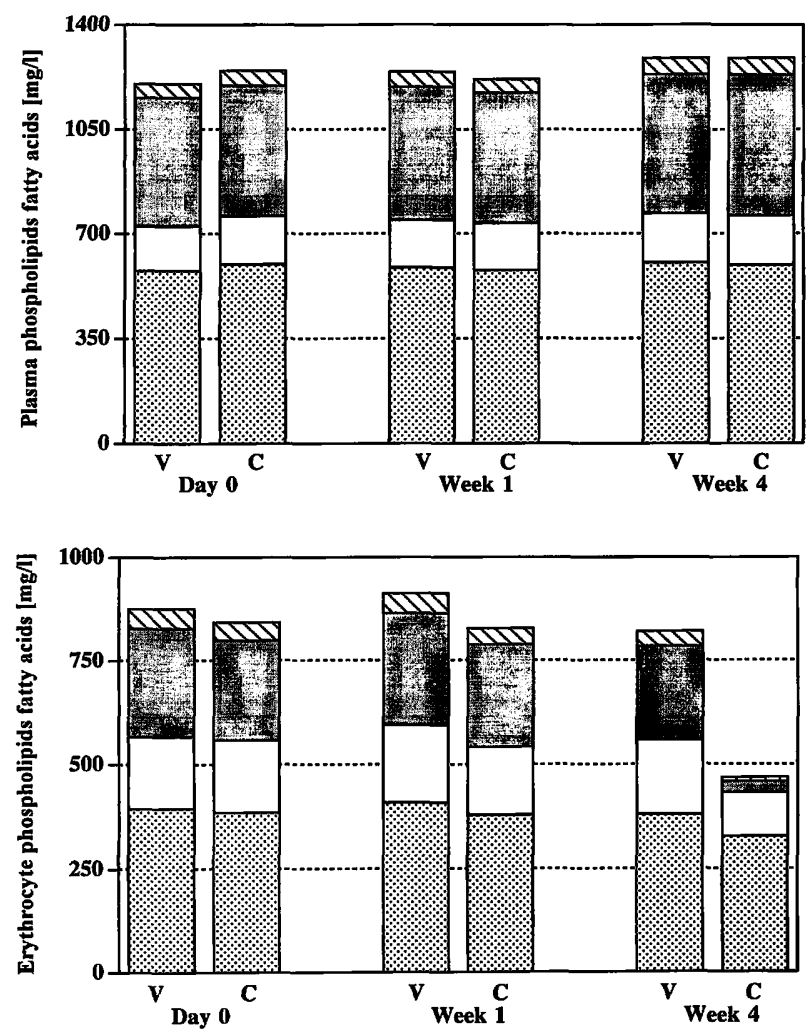

Fig. 1 Absolute fatty acid composition (medians) of venous (V) and capillary $(C)$ plasma and red blood cells phospholipids, stored at $-20^{\circ} \mathrm{C}$ for zero days, one week or four weeks before lipid extraction.

$\mathrm{n}=\mathbf{8}$ for all venous and capillary samples, except for the capillary red blood cell samples of week $1 \mathrm{n}=6$.

웅: sum of all saturated fatty acids; $\square$ : sum of all monounsaturated fatty acids; $\boldsymbol{m}$ : sum of all $\omega-6$ fatty acids and $\$$ : sum of all $\omega-3$ fatty acids. 
Tab. 1 Fatty acid composition of venous and capillary red blood cell phospholipids, with lipid extraction done on the day of collection (day 0 ) and 4 weeks thereafter [median (inter-quartile range)].

\begin{tabular}{|c|c|c|c|c|c|c|c|c|c|}
\hline \multirow[t]{2}{*}{ Fatty acids ${ }^{a}$} & & \multicolumn{4}{|l|}{ Day 0} & \multicolumn{4}{|l|}{ Week 4} \\
\hline & & \multicolumn{2}{|l|}{$\begin{array}{l}\text { Venous } \\
\mathrm{n}=8\end{array}$} & \multicolumn{2}{|c|}{$\begin{array}{l}\text { Capillary } \\
n=8\end{array}$} & \multicolumn{2}{|l|}{$\begin{array}{l}\text { Venous } \\
\mathrm{n}=8\end{array}$} & \multicolumn{2}{|c|}{$\begin{array}{l}\text { Capillary } \\
n=8\end{array}$} \\
\hline Total & [mg/l] & 881.9 & $(345.55)$ & 840.8 & $(281.74)$ & 810.6 & $(241.41)$ & 461.5 & $(136.59)^{\mathrm{c}}$ \\
\hline Saturated fatty acids & [\%] & 44.82 & $(1.48)$ & 45.23 & $(0.73)$ & 46.30 & $(4.93)$ & 66.20 & $(5.95)$ \\
\hline Monounsaturated fatty acids & {$[\%]$} & 20.15 & $(0.95)$ & 19.97 & $(0.96)$ & 21.29 & (3.13) & 24.00 & $(2.57)$ \\
\hline $18: 2 \omega-6$ & {$[\%]$} & 13.16 & $(1.99)$ & 13.25 & $(2.98)$ & 13.00 & $(4.10)$ & 4.34 & $(1.29)^{\mathrm{c}}$ \\
\hline $20: 3 \omega-6$ & {$[\%]$} & 1.32 & $(0.26)$ & 1.30 & $(0.36)$ & 1.08 & $(0.34)$ & 0.22 & $(0.22)^{c}$ \\
\hline $20: 4 \omega-6$ & [\%] & 10.48 & (1.81) & 10.08 & $(1.50)$ & 0.48 & $(1.88)^{c}$ & 0.48 & $(1.60)^{c}$ \\
\hline $22: 4 \omega-6$ & {$[\%]$} & 2.55 & $(0.86)$ & 2.54 & $(0.78)$ & 2.49 & $(0.60)$ & 0.33 & $(0.20)^{\mathrm{c}}$ \\
\hline $22: 5 \omega-6$ & {$[\%]$} & 0.30 & $(0.12)$ & 0.29 & $(0.10)$ & 0.30 & $(0.10)$ & 0.03 & $(0.07)^{\mathrm{c}}$ \\
\hline $\begin{array}{l}\omega-6 \text { long-chain polyunsaturated } \\
\text { fatty acids }\end{array}$ & {$[\%]$} & 14.47 & $(2.43)$ & 14.10 & $(2.30)$ & 13.37 & $(2.00)$ & 1.24 & $(1.58)^{\mathrm{c}}$ \\
\hline $20: 5 \omega-3$ & {$[\%]$} & 0.45 & $(0.35)$ & 0.44 & $(0.39)$ & 0.40 & $(0.40)$ & 0.02 & $(0.15)^{c}$ \\
\hline $22: 5 \omega-3$ & {$[\%]$} & 1.50 & $(0.33)$ & 1.44 & $(0.31)$ & 1.57 & $(0.52)$ & 0.52 & $(0.20)^{\mathrm{c}}$ \\
\hline $22: 6 \omega-3$ & {$[\%]$} & 3.38 & $(1.02)$ & 3.17 & $(0.95)$ & 1.99 & $(1.83)^{\mathrm{c}}$ & 0.51 & $(0.34)^{\mathrm{c}}$ \\
\hline $\begin{array}{l}\omega-3 \text { long-chain polyunsaturated } \\
\text { fatty acids }\end{array}$ & [\%] & 5.47 & (1.64) & 5.05 & (1.66) & 4.06 & (1.73) & 2.01 & $(0.72)^{c}$ \\
\hline Unsaturation index & & 131.3 & $(11.56)$ & 131.4 & $(9.70)$ & 117.5 & $(20.15)^{c}$ & 49.7 & $(12.76)^{c}$ \\
\hline
\end{tabular}

fatty acid profiles after four weeks of storage (fig. 1). The total amount of phospholipid-associated fatty acids decreased to about $55 \%$ of the initial values (tab. 1). The largest decrease $(90.1 \%)$ was observed in the absolute amounts of $\omega-6$ and $\omega-3$ fatty acids (fig. 1).

When expressed as fraction of the total amount of the fatty acids, it was obvious that the decrease concerned the $\omega-6$ long-chain polyunsaturated fatty acids in particular (tab. 1). The levels of $\omega-3$ long-chain polyunsaturated fatty acids declined to about half the initial values.

Values for the unsaturation index, calculated as the sum of [number of double bonds $\times \%$ fraction of the corresponding fatty acid] (7), were also decreased in capillary red blood cell phospholipids after four weeks of storage, again reflecting the loss of unsaturated fatty acids.

\section{Butylated hydroxytoluene and deferoxamine}

The results of the red blood cell samples stored in the presence of butylated hydroxytoluene or deferoxamine are presented in table 2 (see p. 910).

Analyses of the slopes showed a slight but significant decline in the levels of $18: 2 \omega-6(p<0.01)$ in the samples stored in the presence of butylated hydroxytoluene (tab. 2). The deferoxamine samples showed significant increases over time in the levels of $22: 4 \omega-6$ and $22: 5 \omega-6 \quad(p<0.005), \quad 22: 5 \omega-3 \quad$ and $22: 6 \omega-3$ $(p<0.01)$ and the levels of the sum of the monounsa- turated fatty acids and the $\omega-3$ long-chain polyunsaturated fatty acids.

\section{Red blood cell lipid extracts}

Table 3 (see p. 912/913) shows the levels of fatty acids in the phospholipids of the red blood cell lipid extracts which were prepared on the same day of blood collection and stored up to 44 weeks. Significant increases $(p<0.005)$ were observed for the levels of monounsaturated fatty acids and $\omega-3$ long-chain polyunsaturated fatty acids. The slope of the relative levels of $22: 5 \omega-3$ and $22: 6 \omega-3$ also showed a significant increase $(p<0.01)$ in time, whereas the fractions of $18: 2 \omega-6$ decreased significantly $(p<0.005)$.

\section{Discussion}

This study demonstrates that, after four weeks of storage at $-20^{\circ} \mathrm{C}$ before lipid extraction, fatty acid profiles in red blood cell phospholipids isolated from venous and from capillary blood are no longer comparable. This is the result of substantial losses of fatty acids, particulary long-chain polyunsaturated fatty acids, in capillary red blood cells. These long-chain polyunsaturated fatty acids losses were seen to be prevented by adding butylated hydroxytoluene or deferoxamine to red blood cell samples before storage. 


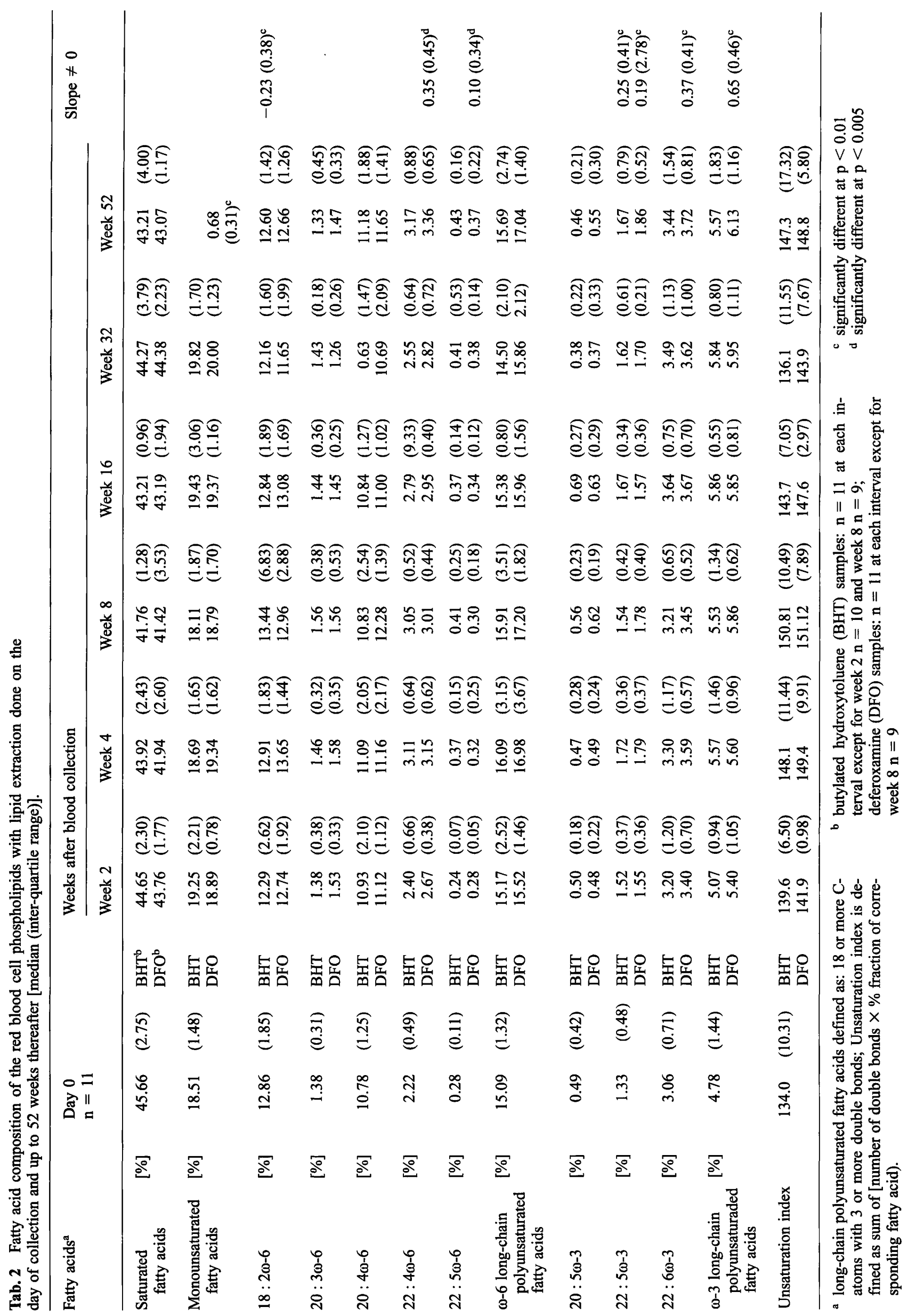


The fatty acid profiles of venous and capillary plasma phospholipids are unaffected by four weeks of storage and remain essentially similar. This enables an accurate evaluation of dietary influences in longitudinal sample sets consisting of both venous and capillary plasma.

Loss of phospholipid-associated polyunsaturated fatty acids from red blood cells as a consequence of storage at temperatures below $0{ }^{\circ} \mathrm{C}$ has been reported by others $(8-10)$. Autoxidation of long-chain polyunsaturated fatty acids is the obvious major cause for the changes observed. In our study, the multiple fatty acid losses were mainly observed in the capillary red blood cell samples. All capillary and none of the venous samples collected in our study showed signs of haemolysis, indicating loss of red blood cell membrane structural integrity. This red blood cell damage may enhance the susceptibility for lipid peroxidation through the release of otherwise sequestered iron, present in haemoglobin, which thus becomes available for the free radical reactions involved in autoxidation (11, 12). Indeed, in contrast to his observations in intact red blood cells, Ways (9) reported that the phospholipid content of haemoglobin-free red blood cell ghosts was not affected by storage under the same conditions.

Attempts had to be made to prevent the observed loss of red blood cell fatty acids. An option was storage of red blood cell suspensions at temperatures below $-20^{\circ} \mathrm{C}$, e.g. at $-50^{\circ} \mathrm{C}$ or even $-80^{\circ} \mathrm{C}$, but this would possibly delay and not prevent lipid loss. Another option was to remove haemoglobin from the red blood cell lipids by preparing red cell ghosts (9) or lipid extracts from the red blood cell within one week after blood sampling. Dodge \& Phillips (8) observed no signs of autoxidation of red blood cell phospholipids in lipid extracts if the antioxidants butylated hydroxytoluene or $\alpha$-tocopherol were present during storage. However, if one wishes all steps of the analyses to be simultaneously performed for a series of consecutive red blood cell samples, storage of red blood cell suspensions is unavoidable. In this case, autoxidation may be prevented by handling and storing the red blood cell samples in the presence of a chelating agent that binds iron and thus prevents it from promoting lipid peroxidation. Knight et al. $(13,14)$ reported that addition of deferoxamine, an iron-chelating agent, to stored whole blood was effective in reducing lipid peroxidation of the red blood cells. In our study, we

\section{References}

1. Kupke IR, Zeugner S, Gottschal A, Kather B. Differences in lipid and lipoprotein concentrations of capillary and venous blood samples. Clin Chim Acta 1979; 97:279-83.

2. Thielmann K, Rühling K, Schauer I, Heller R, Traut H. Suitability and recovery of capillary blood plasma for lipid determinations (in German). Acta Biol Med Germ 1979; 38:1115-21.

3. Bligh E, Dyer WJ. A rapid method for total lipid extraction and purification. Can J Biochem Physiol 1959; 37:911-7. assessed the ability of deferoxamine and butylated hydroxytoluene to protect against long-chain polyunsaturated fatty acids loss from red blood cell samples stored at a temperature of $-50^{\circ} \mathrm{C}$. Our findings showed no reduction of the phospholipid-associated long-chain polyunsaturated fatty acids as observed earlier in the capillary red blood cell samples after four-week storage. This was supported by the unsaturation index, which showed no changes over time in the samples (tab. 2 and $3)$. In contrast, $\omega-3$ long-chain polyunsaturated fatty acids levels of the samples stored in the presence of deferoxamine showed a significant increase of the slopes (tab. 2), the reason for which is unknown. This also holds for the observed increase in the $\omega-3$ fatty acids in the red blood cell lipid extracts prepared on the day of blood collection.

However, the levels of $18: 2 \omega-6$ of the samples stored in the presence of butylated hydroxytoluene and the lipid extracts were found to be decreased. This was striking because even the long-chain polyunsaturated fatty acids (containing 3 or more double bonds) showed no significant decrease in time. Vossen et al. (15) showed that the presence of butylated hydroxytoluene during the preparation of $18: 2 \omega-6$ containing liposomes effectively protected against lipid peroxidation induced by $\mathrm{CuSO}_{4} /$ $\mathrm{H}_{2} \mathrm{O}_{2}$; even total inhibition of lipid peroxidation occurred with high amounts of butylated hydroxytoluene.

In conclusion, the results of this study indicate that plasma phospholipid-associated fatty acid profiles of venous and of capillary blood are comparable and unaffected by storage at $-20^{\circ} \mathrm{C}$ for up to four weeks before lipid extraction. However, the fatty acid content of red blood cell suspensions of capillary origin, stored for more than one week before lipid extraction, shows lipid losses, with the largest decreases observed in the highly unsaturated fatty acids. Both butylated hydroxytoluene and deferoxamine combined with storage at $-50^{\circ} \mathrm{C}$ appeared to protect these long-chain polyunsaturated fatty acids against deterioration upon storage of red blood cells.

\section{Acknowledgements}

The authors gratefully acknowledge the assistance of Marianne Simonis and Hasibe Aydeniz for their technical assistance and Arnold Kester for the statistical advice.
4. Kaluzny MA, Duncan LA, Merritt MV, Epps DE. Rapid separation of lipid classes in high yield and purity using bonded phase columns. J Lipid Res $1985 ; 26: 135-40$.

5. Morrisson WR, Smith LM. Preparation of fatty acid methyl esters and dimethylacetals from lipids with borontrifluoridemethanol. J Lipid Res 1964; 5:600-8.

6. Foreman-v Drongelen MMHP, Houwelingen ACv, Kester ADM, de Jong AEP, Blanco CE, Hasaart THM, et al. Long chain polyene status of preterm infants with regard to the fatty 
Tab. 3 Fatty acid composition of the red blood cell extract phospholipids analyzed after storage up to 44 weeks [median interquartile range)].

\begin{tabular}{|c|c|c|c|c|c|c|c|c|c|c|c|}
\hline \multirow[t]{2}{*}{ Fatty acids ${ }^{\mathrm{a}}$} & & \multirow{2}{*}{$\begin{array}{l}\text { Day } 0 \\
\mathrm{n}=11\end{array}$} & & \multicolumn{8}{|c|}{ Weeks after lipid extraction ${ }^{d}$} \\
\hline & & & & $\begin{array}{l}4 \\
\mathrm{n}=11\end{array}$ & & $\begin{array}{l}8 \\
n=11\end{array}$ & & $\begin{array}{l}12 \\
\mathrm{n}=11\end{array}$ & & $\begin{array}{l}16 \\
\mathrm{n}=11\end{array}$ & \\
\hline $\begin{array}{l}\text { Saturated } \\
\text { fatty acids }\end{array}$ & {$[\%]$} & 45.66 & $(2.75)$ & 44.57 & $(2.83)$ & 46.16 & $(0.73)$ & 44.06 & $(3.51)$ & 44.58 & $(1.47)$ \\
\hline $\begin{array}{l}\text { Monounsaturated } \\
\text { fatty acids }\end{array}$ & {$[\%]$} & 18.51 & (1.48) & 18.09 & $(1.30)$ & 19.06 & $(0.87)$ & 18.60 & $(1.83)$ & 18.74 & (1.43) \\
\hline $18: 2 \omega-6$ & {$[\%]$} & 12.86 & $(1.85)$ & 12.25 & $(1.73)$ & 12.15 & $(1.65)$ & 13.11 & $(3.12)$ & 12.27 & $(1.91)$ \\
\hline $20: 3 \omega-6$ & {$[\%]$} & 1.38 & $(0.31)$ & 1.32 & $(0.39)$ & 1.43 & $(0.25)$ & 1.43 & $(0.28)$ & 1.47 & $(0.27)$ \\
\hline $20: 4 \omega-6$ & {$[\%]$} & 10.78 & $(1.25)$ & 11.20 & $(2.12)$ & 10.71 & $(1.45)$ & 10.65 & $(2.49)$ & 10.70 & $(1.34)$ \\
\hline $22: 4 \omega-6$ & {$[\%]$} & 2.22 & $(0.49)$ & 2.87 & $(0.54)$ & 2.46 & $(0.25)$ & 2.50 & $(0.49)$ & 2.66 & $(0.50)$ \\
\hline $22: 5 \omega-6$ & {$[\%]$} & 0.28 & $(0.11)$ & 0.34 & $(0.17)$ & 0.31 & $(0.13)$ & 0.32 & $(0.13)$ & 0.41 & $(0.15)$ \\
\hline $\begin{array}{l}\omega-6 \text { long-chain } \\
\text { polyunsaturated } \\
\text { fatty acids }\end{array}$ & {$[\%]$} & 15.09 & $(1.32)$ & 16.11 & $(3.07)$ & 15.23 & (1.89) & 14.95 & $(4.11)$ & 15.65 & $(1.05)$ \\
\hline $20: 5 \beta-3$ & {$[\%]$} & 0.49 & $(0.42)$ & 0.46 & $(0.22)$ & 0.56 & $(0.23)$ & 0.34 & $(0.23)$ & 0.51 & $(0.24)$ \\
\hline $22: 5 \omega-3$ & {$[\%]$} & 1.33 & $(0.48)$ & 1.63 & $(0.39)$ & 1.56 & $(0.34)$ & 1.55 & $(0.42)$ & 1.57 & $(0.40)$ \\
\hline $22: 6 \omega-3$ & {$[\%]$} & 3.06 & $(0.71)$ & 3.61 & $(0.89)$ & 3.20 & $(0.73)$ & 3.30 & $(1.00)$ & 3.16 & $(0.79)$ \\
\hline $\begin{array}{l}\omega-3 \text { long-chain } \\
\text { polyunsaturated } \\
\text { fatty acids }\end{array}$ & & 4.78 & $(1.44)$ & 5.70 & $(0.90)$ & 5.18 & $(0.95)$ & 5.32 & $(1.06)$ & 5.41 & $(0.97)$ \\
\hline Unsaturation index & & 132.3 & $(10.97)$ & 144.1 & $(10.24)$ & 136.8 & (6.76) & 138.8 & (10.66) & 140.2 & (6.59) \\
\hline
\end{tabular}

a long-chain polyunsaturated fatty acids defined as: 18 or more $\mathrm{C}-\quad \mathrm{b}$ significantly different at $\mathrm{p}<0.01$ atoms with 3 or more double bonds; Unsaturation index is de- ${ }^{c}$ significantly different at $p<0.005$ fined as sum of [number of double bonds $\times \%$ fraction of corre- ${ }^{d}$ there are no data available for week 20 sponding fatty acid].

acid composition of their diet: comparison between absolute and relative fatty acid levels in plasma and erythrocyte phospholipid. Br J Nutr 1995; 73:405-22.

7. Hoffman DR, Uauy R. Essentially of dietary $\omega-3$ fatty acids for premature infants: plasma and red blood cell fatty acid composition. Lipids 1992; 27:886-95.

8. Dodge JT, Phillips GB. Autoxidation as a cause of altered lipid distribution in extracts from human and red cells. J Lipid Res 1966; 7:387-95.

9. Ways PO. Degradation of glycoerophosphatides during storage of saline-washed, saline-suspended red cells at $-20^{\circ} \mathrm{C}$. J Lipid Res 1967; 8:518-21.

10. Glatz JFC, Soffers AEMF, Katan MB. Fatty acid composition of serum cholesteryl esters and erythrocyte membranes as indicators of linoleic acid intake in man. Am J Clin Nutr 1989; 49:269-76.

11. Chiu D, Kuypers F, Lubin B. Lipid peroxidation in human red cells. Semin Hematol 1989; 26:257-76.
12. Gutteridge JMC. Iron and oxygen: a biologically damaging mixture. Acta Pædiat Scand Suppl 1989; 361:78-85.

13. Knight JA, Voorhees RP, Martin L. The effect of metal chelators on lipid peroxidation in stored erythrocytes. Ann Clin Lab Sci 1992; 22:207-13.

14. Knight JA, Searles DA, Clayton FC. The effect of desferrioxamine on stored erythrocytes: lipid peroxidation, deformability, and morphology. Ann Clin Lab Sci 1996; 26:283-90.

15. Vossen RC, Dam-Mieras van MC, Hornstra G, Zwaal RF. Continuous monitoring of lipid peroxidation by measuring conjugated diene formation in an aqueous liposome suspension. Lipids $1993 ; 28: 857-61$.

\section{Received July 3/October 16, 1997}

Corresponding author: Suzie J. Otto, Universiteit Maastricht, Vakgroep Humane Biologie, Universiteitssingel 50, NL-6229 ER Maastricht, The Netherlands 
Tab. 3

(continued)

\begin{tabular}{|c|c|c|c|c|c|c|c|c|c|c|c|c|}
\hline \multicolumn{12}{|c|}{ Weeks after lipid extraction ${ }^{d}$} & \multirow{3}{*}{ slope $\neq 0$} \\
\hline $\begin{array}{l}24 \\
n=11\end{array}$ & & $\begin{array}{l}28 \\
\mathrm{n}=11\end{array}$ & & $\begin{array}{l}32 \\
n=10\end{array}$ & & $\begin{array}{l}36 \\
n=10\end{array}$ & & $\begin{array}{l}40 \\
n=11\end{array}$ & & $\begin{array}{l}44 \\
n=11\end{array}$ & & \\
\hline 46.32 & $(0.67)$ & 42.08 & $(1.06)$ & 43.95 & $(2.85)$ & 43.50 & $(0.85)$ & 43.57 & $(1.45)$ & 43.14 & $(1.05)$ & \\
\hline 18.92 & $(1.17)$ & 19.00 & (1.49) & 19.68 & $(1.27)$ & 22.60 & $(0.89)$ & 20.40 & $(1.05)$ & 20.98 & $(2.74)$ & $0.07(0.03)^{\mathrm{c}}$ \\
\hline 12.28 & $(2.05)$ & 12.59 & $(1.55)$ & 11.81 & $(2.11)$ & 11.87 & (1.04) & 12.47 & (1.63) & 12.22 & $(0.71)$ & $-0.02(0.02)^{c}$ \\
\hline 1.28 & $(0.24)$ & 1.60 & $(0.37)$ & 1.22 & $(0.29)$ & 1.10 & $(0.25)$ & 1.25 & $(0.30)$ & 1.38 & $(0.72)$ & \\
\hline 10.53 & $(1.55)$ & 12.00 & $(2.42)$ & 10.49 & $(2.60)$ & 10.64 & (1.94) & 10.97 & $(1.40)$ & 11.66 & $(2.46)$ & \\
\hline 2.97 & $(0.33)$ & 2.64 & $(0.38)$ & 2.74 & $(0.53)$ & 2.82 & $(0.39)$ & 2.66 & $(0.44)$ & & & \\
\hline 0.22 & $(0.06)$ & 0.40 & $(0.14)$ & 0.34 & $(0.08)$ & 0.32 & $(0.12)$ & 0.23 & $(0.19)$ & 0.29 & $(0.37)$ & \\
\hline 14.75 & $(2.21)$ & 17.02 & $(2.58)$ & 15.36 & $(2.63)$ & 14.94 & (2.11) & 15.57 & $(1.26)$ & 16.20 & $(3.02)$ & \\
\hline 0.45 & $(0.23)$ & 0.53 & $(0.34)$ & 0.43 & $(0.25)$ & 0.43 & $(0.28)$ & 0.59 & $(0.41)$ & 0.57 & $(0.29)$ & \\
\hline 1.48 & $(0.28)$ & 1.63 & $(0.29)$ & 1.40 & $(0.59)$ & 1.54 & $(0.42)$ & 1.66 & $(6.47)$ & 1.92 & $(0.58)$ & $0.01(0.01)^{b}$ \\
\hline 3.00 & $(0.35)$ & 3.62 & $(0.71)$ & 3.73 & $(0.79)$ & 3.39 & $(0.69)$ & 3.66 & $(0.71)$ & 4.19 & $(0.71)$ & $0.02(0.01)^{b}$ \\
\hline 4.76 & $(0.71)$ & 5.81 & $(1.42)$ & 5.46 & $(1.00)$ & 5.09 & $(1.02)$ & 5.96 & $(1.41)$ & 6.70 & $(0.92)$ & $0.03(0.02)^{b}$ \\
\hline 133.8 & $(4.90)$ & 151.7 & $(7.57)$ & 139.0 & (6.33) & 138.0 & $(2.23)$ & 141.5 & $(8.71)$ & 152.0 & $(8.75)$ & \\
\hline
\end{tabular}


